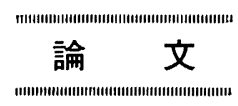

\title{
溶鉄の $\mathrm{Ca}$ 脱酸についで
}

\author{
宮下 芳 雄**.西 川勝 彦**
}

\section{The Deoxidation of Liquid Iron with Calcium}

Yoshio Mryashita and Katsuhiko Nishikawa

\section{Synopsis:}

An investigation was made to clarify the basic feature of deoxidation of liquid iron with calcium. In the experiment, calcium metal was added to the bottom part of liquid iron using a silica tube which was inserted into the liquid iron.

The addition of calcium metal in this way gave the high concentration of calcium in the melt and the rapid decrease of oxygen concentration.

The results ob:ained are as follows:

(1) The concentration of calcium dissolved in the liquid iron is estimated to be at least 0.0103 weight percent at the temperature of $1600^{\circ} \mathrm{C}$ and in the atmosphere of $1 \mathrm{~atm}$.

(2) The reaction $\mathrm{Ca}+\mathrm{O}=\mathrm{CaO}$ proceeds immediately after the addition of calcium and calcium has been proved to be a very powerful deoxidizer having $K^{\prime} \mathrm{ca}=[\% \mathrm{Ca}][\% \mathrm{O}]$ at $1600^{\circ} \mathrm{C}$.

(3) When a small amount of calcium is added to the liquid iron in which primary deoxidation products such as $\mathrm{SiO}_{2}$ or $\mathrm{Al}_{2} \mathrm{O}_{3}$ are suspended, the concentration of oxygen decreases very rapidly to the equilibrium value calculated from the concentration of deoxidizer.

(Received Feb. 25, 1971)

\section{1. 緒言}

鋼の清浄度は脱酸剂，あるいは脱酸の方法によつて著 しい影響をうける. 現在，溶鋼の脱酸は $\mathrm{Mn}, \mathrm{Si}, \mathrm{Al} な$ どの脱酸䯇を出鋼時の溶鋼に添加することによつて行な われているが，最終脱酸戍として Ca 合金を用いると， 非金属介在物の形態や組成が変化し，かつよく脱酸され た鋼が得られるという報告が古くからなされてきた1 3)。また最近においても，IYENGER ら4)，渡辺ら5)，小林 ら6)は小型炉を用いて $\mathrm{Ca}$ 脱酸に関する研究を行なつて いる.

$\mathrm{Ca}$ はO $\mathrm{O}$ と䚇和力がきわめて強いというすぐれた化 学的性質を有しているが，製鋼温度に推ける蒸気圧は高 く, 溶鋼の表面に添加したのでは溶銅中の○に対してほ とんど作用することなく蒸発してしまうため, 脱酸剤と しての効果が認められない場合が多い，そのため溶鉄の $\mathrm{Ca}$ 脱酸に関する基本的な性質については必ずしも統一 的な見解は得られていない.

溶鉄中心おける $\mathrm{Ca}$ の溶解度についても従来不明確で あつたが，最近になつて SPONSELLER らつは液相の $\mathrm{Ca}$ を $1600^{\circ} \mathrm{C}$ で平衡状態に保つことにより，0.032\%の Ca
が溶鉄中に溶解しうるという実験結果を報告した. 本研 究では, SPONSElLER らの実験結果を参考にして, でき るだけ多くの Caを溶鉄中に残留させる方法についてい ろいろ検討してきた結果, Ar ガスを流しながら溶鉄中 に挿入された耐火物パイプを通じて， Ca を少しずつし かも連続的に溶鉄の底部に添加した場合，かなりの $\mathrm{Ca}$ 量が溶鉄中に残留し, しかも溶鉄中の $\mathrm{O}$ は $\mathrm{Ca}$ 添加直後 に急速に減少するということを見いだしたので，この方 法により Caを溶鉄中に添加した場合の Ca 脱酸につい て検討を試みた。

\section{2. 実 験 方 法}

$400 \mathrm{kC}$ 高周波炉を用い, Ar ガス䨌囲気中ですべての 溶解を行なつた. るつぼとしては内径 $53 \mathrm{~mm}$ の $\mathrm{MgO}$ または $\mathrm{Al}_{2} \mathrm{O}_{3}$ るつぼを用い，各実験とも電解鉄（C< $0.003 \%, \mathrm{Mn}, \mathrm{Si}, \mathrm{Al}<0.005 \%) \quad 1 \mathrm{~kg}$ を溶解した． Pt$\operatorname{PtRh}(\mathrm{Rh}=13 \%)$ 熱電対を用いて, 溶鉄の温度を測定し, $1600 \pm 10^{\circ} \mathrm{C}$ の温度ですべての実験を行なつた. 脱酸剤 として, $\mathrm{Si}$ には金属 $\mathrm{Si}(\mathrm{Si}=98 \cdot 4 \%, \mathrm{Fe}=0.6)$ を, $\mathrm{Al}$

\footnotetext{
* 昭和 46 年 2 月 25 日受付

** 日本鋼管 (株) 技術研究所
} 


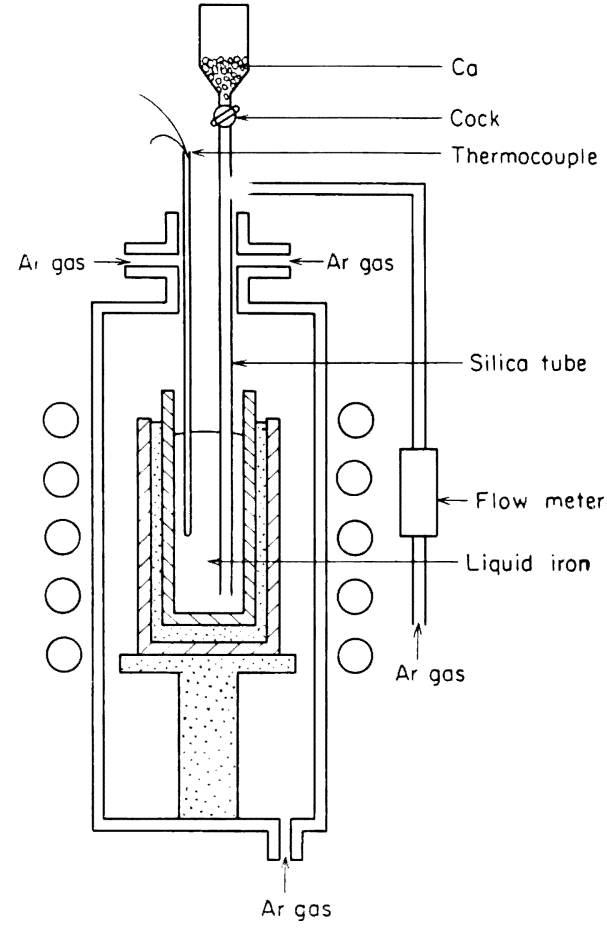

Fig. 1. Schematic diagram of experimental equipment.

には $\mathrm{Fe}-\mathrm{Al}$ 合金 $(\mathrm{Fe}=50 \%, \mathrm{Al}=50 \%)$ を使用した。 また $\mathrm{Ca}$ には直径 $1 \mathrm{~mm}$ 程度の微細な金属 $\mathrm{Ca}$ 粒 $(\mathrm{Ca}=$ 99\%) を用いた.

溶鉄への Ca の添加については, Fig. 1 に示すよう に内径 $5 \mathrm{~mm}$ の石英管をるつぼの底面近くまで㧴入し， Ar ガスを $0.2 \sim 0.3 l / \min$ の割合で流しながら Ca を 自然落下させることにより溶鉄中に添加した．この場合 $\mathrm{Ca}$ を少しずつしかも連続的に添加したため, $1 \mathrm{~g} の \mathrm{Ca}$ を添加するのに通常 20〜30 sec ほど要した：溶鉄へ Ca を添加する時期としては $\mathrm{Si}$ あるいは $\mathrm{Al}$ にて子備脱酸 した後に添加する場合，または予備脱酸なしに $\mathrm{Ca}$ の を添加する場合について実験した。

各種分析用の試料として, 所定の時刻に内径 $5 \mathrm{~mm}$ の 石英管を溶鉄中に浸してすいあげ採取した後，水中で急 冷した．Ｏの分析は真空溶融法によつたが，特にO濃度 の低い試料については真空溶融定容積測圧法により分析 した. $\mathrm{Si}, \mathrm{Al}$ の分析には比色法を用い, $\mathrm{Ca}$ の分析につい ては吸光光度法, 溶液分光法, 直接分光法などによつて いろいろ検討した結果，Ca が $0.001 〜 0.020 \%$ の範囲 においては直接分光法にて問題なく分析できることを確 認できたため，その後は直接分光法によつた．非金属介

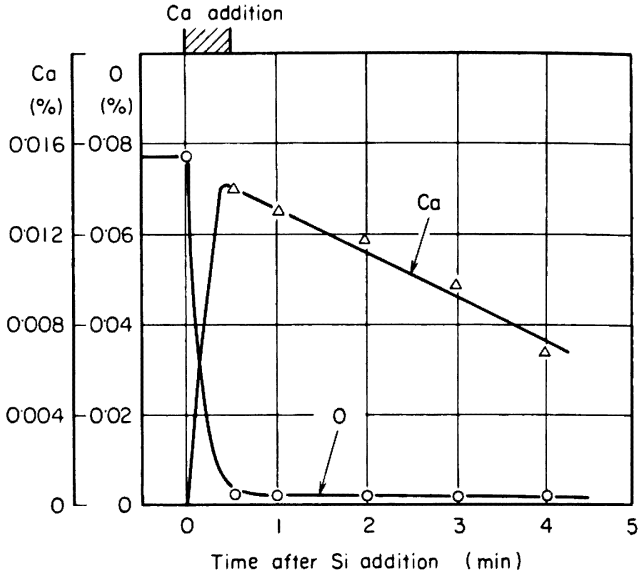

Fig. 2. Change of $\mathrm{O}$ content after the addition of $\mathrm{Ca}$.

在物の観察のためには各試料を十分エメリーペーパーで 研摩した後, ダィヤモンド研摩で仕上げ, 補足的に酸化 クローム研摩を行なつた. 研摩面の介在物を光学顕微鏡 で詳細に観察し，代表的な介在物については XMA に より組成を分析した。

\section{3. 実 験 結 果}

\section{$3 \cdot 1 \mathrm{Ca}$ による単独脱酸}

0.077\% のOを含む溶鉄に 1\%の Ca を添加した場 合の $\mathrm{Ca}$, O の挙動を Fig. 2 に示す. これよりわかる ように，溶鉄中の $\mathrm{Ca}$ 濃度は Ca 添加直後に $0.014 \%$ と かなり高い值を示し, 時間の経過とともに徐々に減少し ている。また溶鉄中のO濃度は $\mathrm{Ca}$ の添加により一挙に $0.0018 \%$ にまで減少し,その後は時間の経過にもかかわ らずほぼ一定の值を示している，なた $\mathrm{Ca}$ を添加した後 の試料中には介在物は非常に少なくなつており, $\mathrm{CaO}$ な どの介在物を観察することはできなかつた・

このように，Oを多㻎に含む溶鉄中に Caを添加した 場合，溶鉄中の $\mathrm{O}$ 濃度はふなり減少し，しかもその減少 は $\mathrm{Ca}$ を溶鉄中に添加しているかなり短い時間のうちに 行なわれている.

この場合，Oの除去に実質的に寄与している $\mathrm{Ca}$ の割 合として, 有効脱酸効率 $f_{\mathrm{Ca}}$ を(1) 式のように定義す る.

$$
f_{\mathrm{Ca}}=\frac{40 / 16\left(\mathrm{O}_{I}-\mathrm{O}_{F}\right)}{\mathrm{Ca}_{I}-\mathrm{Ca}_{F}} \times 100
$$

ここで, $\mathrm{O}_{I}: \mathrm{Ca}$ 添加前のO濃度 $(\%)$

$\mathrm{O}_{F}: \mathrm{Ca}$ 添加後のO 䀼度 $(\%)$

$\mathrm{Ca}_{I}$ : 添加した $\mathrm{Ca}$ の溶鉄に対する割合（\%) 


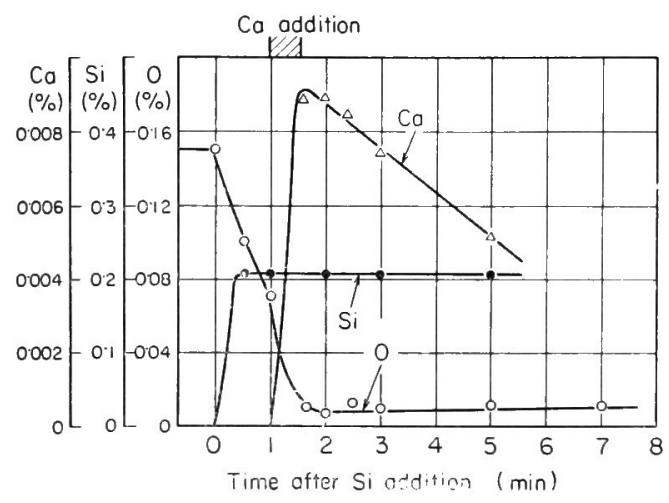

Fig. 3. Effect of $\mathrm{Ca}$ addition on the change of $\mathrm{O}$ content in the process of $\mathrm{Si}$ deoxidation.

Table 1. Composition of inclusions analized by XMA $(\%)$.

\begin{tabular}{l|c|c|c}
\hline \hline & $\mathrm{FeO}$ & $\mathrm{SiO}_{2}$ & $\mathrm{CaO}$ \\
\hline $\begin{array}{l}\text { Inclusion before } \\
\text { Ca addition }\end{array}$ & $2 \cdot 4$ & $91 \cdot 5$ & $\mathrm{tr}$ \\
\hline $\begin{array}{l}\text { Inclusion after } \\
\mathrm{Ca} \text { addition }\end{array}$ & $2 \cdot 6$ & $42 \cdot 4$ & 48.5 \\
\hline
\end{tabular}

\section{$\mathrm{Ca}_{F}: \mathrm{Ca}$ 添加後の $\mathrm{Ca}$ 濃度 $(\%)$}

本実験ておいては $f_{\mathrm{C}_{\mathrm{a}}}=19 \%$ となり, 添加した大部分の $\mathrm{Ca}$ はOの除去に対して実質的に作用していないことが わかる.なお添加 $\mathrm{Ca}$ 量が少ない場合には, $\mathrm{Ca}$ 添加後 の到達 $\mathrm{O}$ 濃度は高く, また Ca の有效脱酸効率 $f_{\mathrm{Ca}}$ は若 千よくなる傾向にあつたが，一般に Ca だけによつて脱 酸するためには多量の $\mathrm{Ca}$ を必要とし，Oを減少させる ためには効率の悪い方法ということができる.

\section{$3.2 \mathrm{Si}$ 脱酸におよぼす Ca 添加の影響}

$0.150 \%$ の $\mathrm{O}$ を含む溶鉄中に $0.3 \%$ の $\mathrm{Si}$ を添加し

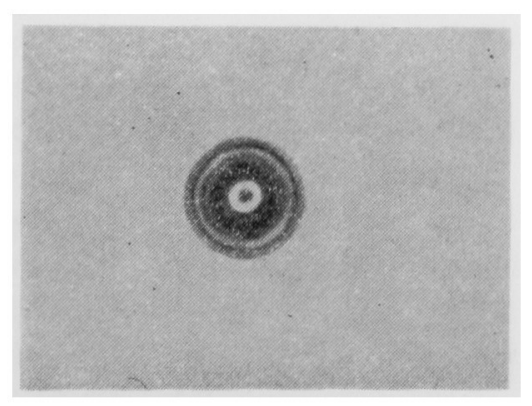

(a) Inclusion before Ca addition

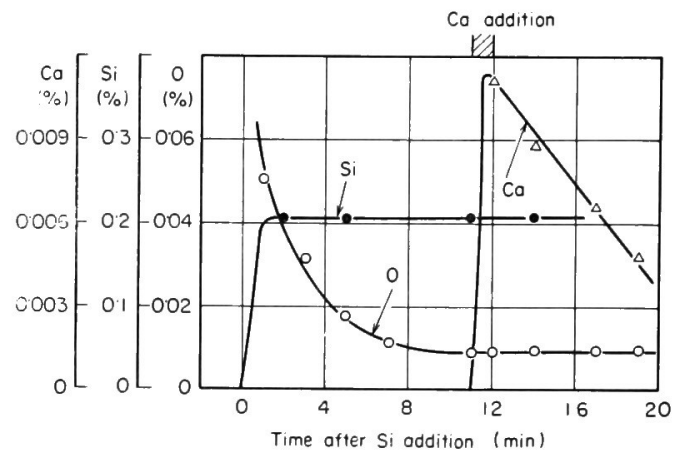

Fig. 4. Effect of $\mathrm{Ca}$ addition on the change of $\mathrm{O}$ content in the process of $\mathrm{Si}$ deoxidation.

て $1 \mathrm{~min}$ 後に $0.06 \%$ の Ca を添加したさいの各成分 の挙動を Fig. 3 に示す. これによると, 溶鉄中の $\mathrm{Ca}$ 濃度は Ca 添加直後に $0.0089 \%$ の值を示し, 時間の経 過とともに減少している。 また溶鉄中のO濃度は $\mathrm{Ca}$ の 添加によりほぼ $\mathrm{Si}$ と平衡するO濃度 0.0106\%にをで 一挙に減少し, その後は一定の值を示している. Ca を 添加した前後の介在物を Photo. 1 に示す。また XMA により分析した值を Table 1 に示す.

Ca 添加前の試料には Photo. 1 (a) に示したような 直径 $10 \sim 20 \mu$ の $\mathrm{SiO}_{2}$ 介在物がかなり多く存在してい るが，Ca を添加した後の試料には直径 3〜 4 $\mu$ 以上の 大きな $\mathrm{SiO}_{2}$ 介在物は見られず，2次脱酸生成物と考え られる直径1〜2 $2 \mu$ の小さな $\mathrm{SiO}_{2}$ 介在物とともにPhoto. 1 (b) に示してあるような直径 7〜8 4 の $\mathrm{SiO}_{2}-\mathrm{CaO}$ 介在物がわずか存在している.しかもこれらの $\mathrm{SiO}_{2}$ $\mathrm{CaO}$ 介在物は $\mathrm{Ca}$ を添加して 2〜3 min 後の試料には ほとえど見られなくなつている。

また Fig. 4 にはO を含む溶鉄中に $0.3 \%$ の Si を 添加して，Oが $\mathrm{Si}$ とほぼ平衡する値に達していると考

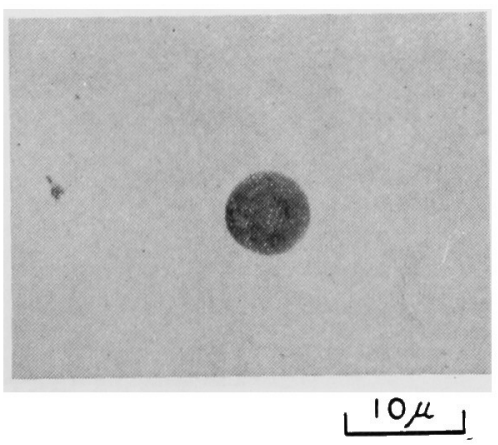

(b) Inclusion after $\mathrm{Ca}$ addition

Photo. 1. Inclusions observed before and after the addition of $\mathrm{Ca}$ in the process of $\mathrm{Si}$ deoxidation. 
えられる $11 \mathrm{~min}$ 後に 0.06\%の Ca荙添加したさいの 各元素の挙動を示す.この場合も溶鉄中のCa 浱度は Ca 添加直後に $0.011 \%$ とかなり高い值を示し, その後は時 間の経過とともに減少している. またOは $\mathrm{Si}$ 添加後徐 々に減少し, $\mathrm{Si}$ を添加して 8〜9 $\mathrm{min}$ 後には $\mathrm{Si}$ と平衡 する值に達しており，Ca 添加によりほとえど変化して いないまた Caを添加した前後の介在物を観察した結 果, 両者ともに 2 次脱酸生成物と考元られる $1 \sim 2 \mu$ の $\mathrm{SiO}_{2}$ 介在物のみが見られ, Photo. 1 (b)のような $\mathrm{SiO}_{2}$ $\mathrm{CaO}$ の介在物を認めることはできなかつた.

このことから Photo. 1 (b)㹸られる $\mathrm{SiO}_{2}-\mathrm{CaO} 介$ 在物は 1 次脱酸生成物である $\mathrm{SiO}_{2}$ が $\mathrm{Ca}$ 添加に上つて 組成を変化したものであると考兵られる.

\subsection{Al 脱酸におよほす Ca 添加の影響}

$0.134 \%$ の O 含む溶鉄に $\mathrm{Fe}-\mathrm{Al} 6 \mathrm{~g}(\mathrm{Al}$ として 0.3\%) を添加して 1 min 後に 0.06\%。の Ca を添加したさい の各元素の挙動を Fig. 5 に示す. 溶鉄中の $\mathrm{Ca}$ 浱度は $\mathrm{Ca}$ 添加直後に 0.009\% に達し，時間の経過とともに 減少している。 また溶鉄中のO 壊度は $\mathrm{Al}$ を添加して 1

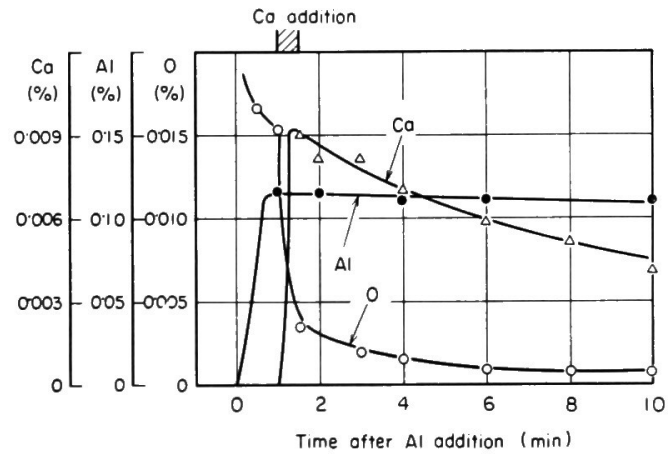

Fig. 5. Effect of $\mathrm{Ca}$ addition on the change of $\mathrm{O}$ content in the process of $\mathrm{Al}$ deoxidation.

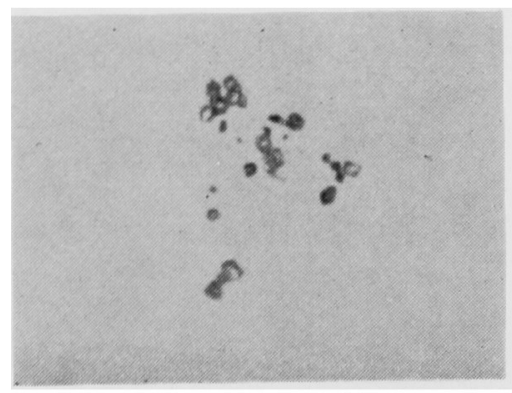

(a) Inclusion before $\mathrm{Ca}$ addition
Table 2. Composition of inclusions analized by XMA $(\%)$.

\begin{tabular}{l|c|c|c}
\hline \hline & $\mathrm{FeO}$ & $\mathrm{Al}_{2} \mathrm{O}_{3}$ & $\mathrm{CaO}$ \\
\hline $\begin{array}{l}\text { Inclusion before } \\
\mathrm{Ca} \text { addition }\end{array}$ & 83.5 & $43 \cdot 7$ & $\mathrm{tr}$ \\
\hline $\begin{array}{l}\text { Inclusion after } \\
\mathrm{Ca} \text { addition }\end{array}$ & 42.5 & $43 \cdot 7$ & $12 \cdot 0$ \\
\hline
\end{tabular}

min 後に 0.015\%にをで減少しているが, Ca の添加に より一挙に 0.0037\% に達し, その後も徐々に減少して 6 min 後には $0.0006 \%$ と非常汇低い值に達している.

Photo. 2 には Ca 添加後の介在物を示し, Table 2 に XMA により分析したそれぞれの組成を示す，Ca を添 加する前の試料には Photo. 2（a ）に示したようなクラ スター状の $\mathrm{Al}_{2} \mathrm{O}_{3}$ 介在物が存在しているが， $\mathrm{Ca}$ を添加 した後の試料にはこのような $\mathrm{Al}_{2} \mathrm{O}_{3}$ 介在物は見られず, Photo. 2 (b)に示したような直径 4 〜 $5 \mu$ 以下の丸い介 在物が存在している. なお Table 2 の分析結果による と，いずれも $\mathrm{FeO}$ をかなり含んでいるが，これは小さ な介在物であるため XMA で分析する場合，マトリッ クスである Fe の影響をかなり強くうけているためと考 えられ，実際には $\mathrm{Al}_{2} \mathrm{O}_{3}$ 介在物と $\mathrm{Al}_{2} \mathrm{O}_{3}-\mathrm{CaO}$ 介在物 であると推定される.

Fig. 6 には Al を添加して，O がほぼ一定值に達し たと考えられる $5 \mathrm{~min}$ 後に $1 \%$ の Ca を添加したさい の各元素の挙動を示す．この場合も溶鉄中の $\mathrm{Ca}$ 濃度は $\mathrm{Ca}$ 添加直後に 0.0143\% となり高い值を示し，時間の 経過とともに減少している。また 举に $0.0006 \%$ と非常に低い值にまで減少し，その後は 時間の経過にかかわらずほぼ一定の值を示している.

このように $\mathrm{Al}$ 脱酸後に $\mathrm{Ca}$ を添加した場合，溶鉄中 の $\mathrm{O}$ 濃度は通常の $\mathrm{Al}$ 脱酸ではとうてい得られないよう な低い值にまで急速に減少している。

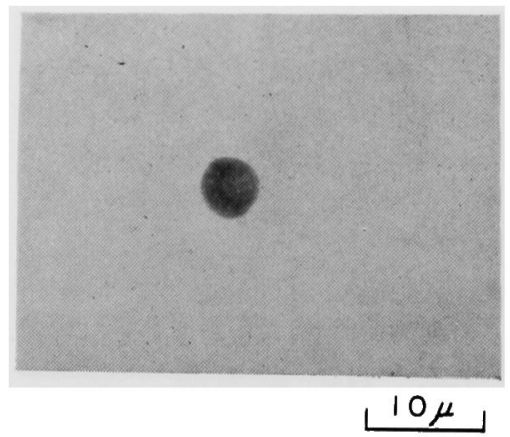

(b) Inclusion after $\mathrm{Ca}$ addition

Photo. 2. Inclusions observed before and after the addition of $\mathbf{C a}$ in the process of $\mathrm{Al}$ deoxidation. 


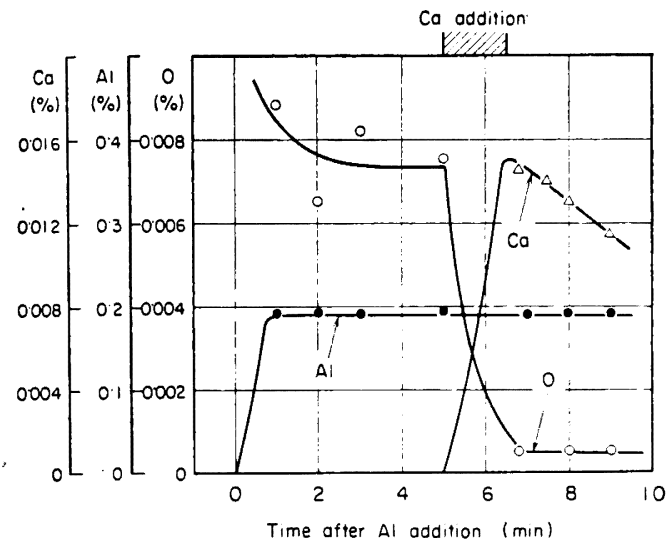

Fig. 6. Effect of $\mathrm{Ca}$ addition on the change of $\mathrm{O}$ content in the process of $\mathrm{Al}$ addition.

\subsection{Si および Al 脱酸におよぼす Ar ガス吹込みの 影響}

本実験では $\mathrm{Ar}$ ガスを吹込みながら $\mathrm{Ca}$ を添加してい るため，Oの变化に対する Ar ガス吹込みの影響を明確 にしておく必要がある.

$0.142 \%$ の Oを含む溶鉄に $0.3 \%$ の $\mathrm{Si}$ を添加して, $1 \mathrm{~min}$ 後に $0.3 \mathrm{l} / \mathrm{min}$ の割合いで $30 \mathrm{sec}$ 間溶鉄中に $\mathrm{Ar}$ ガスを吹込んださいの $\mathrm{O}, \mathrm{Si}$ の挙動を Fig. 7 に示 す. をた $0.153 \%$ の O を含む溶鉄に $\mathrm{Ae}-\mathrm{Al} 6 \mathrm{~g}$ ( $\mathrm{Al}$ として $0.3 \%$ を添加して $1 \mathrm{~min}$ 後に $0.3 \mathrm{l} / \mathrm{min}$ の割 合いで $30 \mathrm{sec}$ 間 $\mathrm{Ar}$ ガスを吹込んださいの $\mathrm{O}, \mathrm{Al}$ の挙 動を Fig. 8 に示す.

これらの図から明らかなように， $\mathrm{Si}, \mathrm{Al}$ 脱酸いずれの 場合にも $\operatorname{Ar}$ ガスの吹込みによつて1次脱酸生成の分離 速度はほとんど影響をうけていないことがわかる。

\section{4. 実験結果の考察}

\section{1 溶鉄中における溶解 $\mathrm{Ca}$ の沙度}

$\mathrm{Ca}$ が液相として溶鉄と接する場合はガス相として接 する場合に比べると，溶鉄中における $\mathrm{Ca}$ の沙度を高め る上では非常に有利である. 本穾験に打けるように, Ca を溶鉄の下部へ少量ずつしかも連続的に添加する場合, 添加された $\mathrm{Ca}$ は $1600^{\circ} \mathrm{C}, 1 \mathrm{~atm}$ の溶鉄中では最終的 には気化するが，溶鉄中を上昇する過程で過渡的に液相 として存在しえるし，溶鉄との接触面積も増大し，また 接触時間も延長するため, 他の添加方法にくらべ $\mathrm{Ca}$ 裖 度を高めうることが理解できる。

溶鉄中における $\mathrm{Ca}$ は (2) 式に示すように溶解してい る $\mathrm{Ca}$ と化合物としての $\mathrm{Ca}$ とに分けられる。

$$
\mathrm{Ca}_{T}=\underline{\mathrm{Ca}}+(\mathrm{Ca})_{\mathrm{com}}
$$

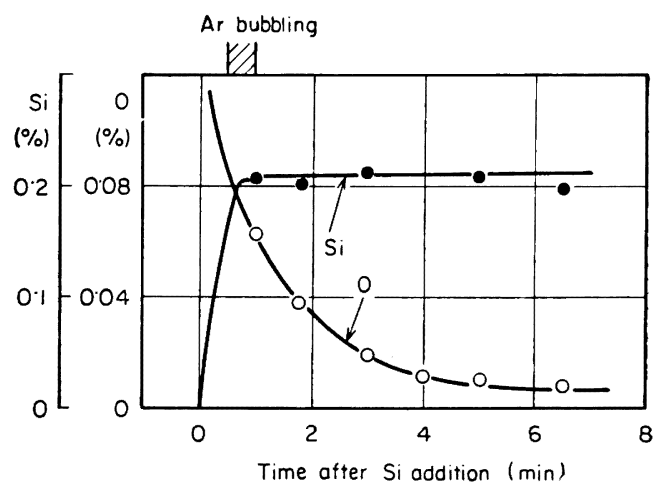

Fig. 7. Effect of Ar gas bubbling on the change of $\mathrm{O}$ content in the process of $\mathrm{Si}$ deoxidation.

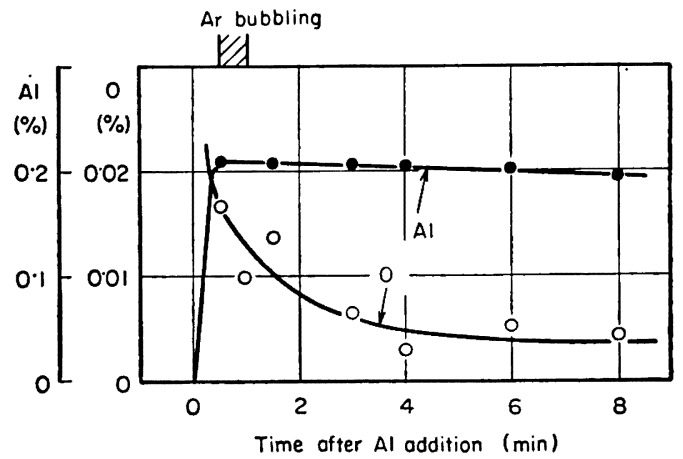

Fig. 8. Effect of Ar gas bubbling on the change of $\mathrm{O}$ content in the process of $\mathrm{Al}$ deoxidation.

Table 3. Contents of elements at $0.5 \mathrm{~min}$ after $\mathrm{Ca}$ addition (\%).

\begin{tabular}{c|c|c|c|c}
\hline $\begin{array}{c}\text { Time after } \mathrm{Ca} \\
\text { addition }\end{array}$ & $\mathrm{Ca}$ & $\mathrm{O}$ & $\mathrm{S}$ & $\mathrm{C}$ \\
\hline $0.5 \mathrm{~min}$ & 0.0140 & 0.0018 & 0.003 & 0.004 \\
\hline
\end{tabular}

ここで, $\mathrm{Ca}_{T}:$ 全 $\mathrm{Ca}$

$\mathrm{Ca}:$ 溶解している $\mathrm{Ca}$

$(\mathrm{Ca})_{\text {com }}$ : 化合物としての $\mathrm{Ca}$

Fig. 2 には溶鉄に 1\% の Ca を添加したさいの O, $\mathrm{Ca}$ の挙動が示されているが，Ca を添加して $30 \mathrm{sec}$ 後 に採取した試料中に含まれる微量元素のうち，溶鉄中で $\mathrm{Ca}$ と化合物を作る可能性のある $\mathrm{O}, \mathrm{S}, \mathrm{C}$ 老分析して Table 3 に示す.

$\mathrm{C}$ との化合物 $\mathrm{CaC}_{2}$ は SPONSELLER らの研究7による と，溶鉄と液相 $\mathrm{Ca}$ が接触する場合にも $\mathrm{C}<0.87 \%$ で は生成しえないとされていることから，本実験において 
はこれを考虑する必要はない."したがつてこの場合 (2) 式は(3)式のように表わすことができる.

$$
\mathrm{Ca}_{T}=\underline{\mathrm{Ca}}+(\mathrm{Ca})_{\mathrm{CaO}}+(\mathrm{Ca})_{\mathrm{CaS}}
$$

ただし，(Ca) $\mathrm{CaO}_{\mathrm{O}}: \mathrm{CaO}$ として存在している $\mathrm{Ca}$

$$
\text { (Ca) } \mathrm{CaS}_{\mathrm{S}} \mathrm{CaS} \text { として存在している } \mathrm{Ca}
$$

ここで Table 3 に示しているO, S のすべてが $\mathrm{Ca}$ と結びついていると仮定すれば， $(\mathrm{Ca})_{\mathrm{CaO}},(\mathrm{Ca})_{\mathrm{Cas}}$ の 值は次の上うに求めることができる。

$(\mathrm{Ca})_{\mathrm{CaO}}=(40 / 16) \times 0.0018=0.0045 \%$

(Ca) $\mathrm{Cas}_{\mathrm{s}}=(40 / 32) \times 0.003=0.0038 \%$

したがつて， $\mathrm{Ca}_{T}$ は 0.0140\% であるから，(3) 式 より Ca として0.0057\% の值が得られる. この場合, 実際には $\mathrm{O}, \mathrm{S}$ のすべてが $\mathrm{Ca}$ と結びついているわけ ではないため，真の $\mathrm{Ca}$ の值は 0.0057\% 上り大きいこ とになる.すなわち，1\%の の $\mathrm{Ca}$ を添加して $30 \mathrm{sec}$ 後の 溶鉄中には少なくとも $0.0057 \%$ の Caが溶解していた と考えてよい。

Fig. 6 には Al を添加して 5 min 後に $1 \%$ の $\mathrm{Ca}$ を 添加したさいの $\mathrm{O}, \mathrm{Ca}$ の挙動が示されているが，この 場合についても同様の計算を試みてみる、Ca を添加し て $1.75 \mathrm{~min}$ 後に溶鉄中より採取した試料について $\mathrm{Ca}$ と化合物を作る可能性のある元素の分析値をTable 4 に 示す.

$\mathrm{CaC}_{2}$ の存在はすでに論じたように本成分采では考元 られず，この場合にも( 3 )式が成立すると考えてよい． ここで Table 4 の $\mathrm{O}, \mathrm{S}$ がすべて $\mathrm{Ca}$ と結びついて いると仮定すれば，(Ca) cao，(Ca) $\mathrm{Cas}$ はそれぞれ次の ように求めることができる.

(Ca) $\mathrm{CaO}=(40 / 16) \times 0.0006=0.0015 \%$

$(\mathrm{Ca})_{\mathrm{Cas}}=(40 / 32) \times 0.002=0.0025 \%$

ここで $\mathrm{Ca}_{T}$ の值は $0.0143 \%$ であるから，(3) 式よ り $\mathrm{Ca}$ として 0.0103\% の值を算出することができる. この場合にも $(\mathrm{Ca})_{\mathrm{CaO}},(\mathrm{Ca}) \mathrm{Cas}$ については前と同様の 考虑が必要である.したがつて溶鉄中に $\mathrm{Ca}$ を添加した 直後には少なくとも $0.0103 \%$ の Ca が溶解していたと 考えてよい。

この $0.0103 \%$ の值はさきに Fig. 2 の実騇例につい て求めた $0.0057 \%$ の值よりかなり大きな值となつてい るが，これは $\mathrm{Ca}$ 添加時の溶鉄中に含まれている $\mathrm{O}$ 浱度

Table 4. Contents of elements at $1.75 \mathrm{~min}$ after $\mathrm{Ca}$ addition (\%).

\begin{tabular}{c|c|c|c|c}
\hline \hline $\begin{array}{c}\text { Time after Ca } \\
\text { addition }\end{array}$ & $\mathrm{Ca}$ & $\mathrm{O}$ & $\mathrm{S}$ & $\mathrm{C}$ \\
\hline $1.75 \mathrm{~min}$ & 0.0143 & 0.0006 & 0.002 & 0.010 \\
\hline
\end{tabular}

の差によるものと考元れる.すなわち，条件さえとと のえば $1 \mathrm{~atm}$ 下の溶鉄中に $0.0103 \%$ 以上の $\mathrm{Ca}$ が溶 解しうることが実験的に証明されたことになる.

小林ら ${ }^{6)}$ は本研究における方法とほぼ同じ方法を用い て実験を行ない，1 atm 下の溶鉄中における $\mathrm{Ca}$ の溶解 量は $0.0030 \%$ 以下であると報告している. SPONSELLER ら》は $1600^{\circ} \mathrm{C}$ の溶鉄を液相の $\mathrm{Ca}$ と接触させ，0.032 $\% の \mathrm{Ca}$ が溶鉄中に溶解しうると報告している. $1600^{\circ}$ $\mathrm{C}$ における $\mathrm{Ca}$ の蒸気圧は $2 \mathrm{~atm}$ であることを考光る と，1 atm 下の溶鉄中における $\mathrm{Ca}$ の溶解度は $0.016 \%$ になる.

$\mathrm{Ca}$ を可能な限り溶解させようと試みた Fig. 6 の実 験例に㨟いても $\mathrm{Ca}_{T}=0.0143 \%, \mathrm{Ca}>0.0103 \%$ という 值が得られていることから，Ca の溶解度に関するSPONSELLER らの実験結果はかなり信頼性のあるものと考え られる.

\subsection{Ca の脱酸力}

Fig. 2 に示したように，溶鉄中に $1 \%$ の $\mathrm{Ca}$ を添加 した場合，Oは $0.077 \%$ から $0.0018 \%$ と非常に低い值 にまで減少している。このことは溶鉄中で $\mathrm{Ca}$ と合が (4) 式の化学反応を起こし, 生成された $\mathrm{CaO}$ (または $\mathrm{FeO}-\mathrm{CaO})$ が溶鉄から分離していることを示している.

$$
\underline{\mathrm{Ca}}+\underline{\mathrm{O}}=\mathrm{CaO}
$$

Fig. 2 に示した実験において, $\mathrm{Ca}$ 添加後 2 min まで の $\mathrm{Ca}$ とOの濃度より $K^{\prime} \mathrm{Ca}(=[\% \mathrm{Ca}][\% \mathrm{O}])$ を計算し Table 5 に示す.

溶鉄中のO 濃度はほとえど变化していないが， Ca 濃 度は時間の経過とともに減少しているため, $\mathrm{Ca}$ と足の 平衡が成立している時間は縤密には $\mathrm{Ca}$ 添加中または添 加直後に限られるとみるべきである.しかし Ca の減少 速度が比較的小さいことを考虑すると $\mathrm{Ca}$ を添加して $0.5 \mathrm{~min}$ 後においても $\mathrm{Ca}$ と兰の平衡はほぼ成立して いると考えてさしつかえない，このときの $K^{\prime} \mathrm{Ca}(=[\%$ $\mathrm{Ca}][\% \mathrm{O}])$ の值として $2.5 \times 10^{-5}$ が得られる. Ca と O の平衡定数は $\mathrm{Ca}$, 首の正確な值を決定できる方法が ないため求めることはできないが, $K^{\prime} \mathrm{Ca}_{\mathrm{a}}=2.5 \times 10^{-5}$ の 值はかなり小さく, $\mathrm{Ca}$ の脱酸力の強いことがわかる.

Table 5. Contents of $\mathrm{O}$ and $\mathrm{Ca}$ after $\mathrm{Ca}$ addition and value of $K^{\prime} \mathrm{Ca}$ calculated from contents of $\mathrm{O}$ and $\mathrm{Ca}$.

\begin{tabular}{c|c|c|c}
\hline \hline $\begin{array}{l}\text { Time after } \mathrm{Ca} \\
\text { addition }\end{array}$ & {$[\% \mathrm{O}]$} & {$[\% \mathrm{Ca}]$} & $\begin{array}{r}K^{\prime} \mathrm{Ca}=[\% \mathrm{Ca}] \\
{[\% \mathrm{O}]}\end{array}$ \\
\hline $0.5 \mathrm{~min}$ & 0.0018 & 0.0140 & $2.5 \times 10^{-5}$ \\
$1 \mathrm{~min}$ & 0.0014 & 0.0130 & $1.8 \times 10^{-5}$ \\
$2 \mathrm{~min}$ & 0.0016 & 0.0118 & $1.9 \times 10^{-5}$ \\
\hline
\end{tabular}


なお，小林らすは $1550^{\circ} \mathrm{C}$ において $K^{\prime} \mathrm{Ca}=1.5 \times 10^{-5}$ を 報告している.

\subsection{Si および Al 脱酸におよぼす Ca 添加の影響}

Fig. 3 に見られるように，溶鉄に $\mathrm{Si}$ を添加して1次 脱酸生成物が多量に存在している ${ }^{8)} 1 \mathrm{~min}$ 後に $0.06 \%$ の $\mathrm{Ca}$ 学添加した場合, 溶鉄中のO濃度は $\mathrm{Ca}$ 添加直後 に $\mathrm{Si}$ と平衡するO濃度まで急速に隇少している. しか し Si を添加して 1 次脱酸生成物の分離がほぼ終了して いる $11 \mathrm{~min}$ 後に等量 $(0.06 \%)$ の $\mathrm{Ca}$ を添加したさい には Fig. 4 に示してあるように，溶鉄中のO浱度はほ とんど減少していないことがわかる. すなわち，1 次脱 酸生成物としての $\mathrm{SiO}_{2}$ が存在している溶鉄中に少量の Ca を添加する場合, 1 次脱酸生成物の分離は促進され, 溶鉄中のO浱度は溶解 $\mathrm{O}$ 值にまで急速に減少するが $\mathrm{Ca}$ と O の化学反応はほとんど進行しないことを示してい る. この場合大量の $\mathrm{Ca}$ を添加すれば $\mathrm{Ca}$ と $\mathrm{O}$ の化学 反応は進行し, 溶解 $\mathrm{O}$ が隇少することはいうまでもな w.

同様に Al を添加して $1 \mathrm{~min}$ 後に0.06\% の Ca を 添加したさいのOの挙動は Fig. 5 からわかるように, $\mathrm{Ca}$ の添加直後にかなり急速に減少し, Si 脱酸の場合と 異なりその後も徐々に減少して通常の $\mathrm{Al}$ 脱酸では得ら れないほど低いO濃度 $0.0006 \%$ にまで達している。 こ のようなOの低濃度は Fig. 6 においても同様に見られ ている.

$\mathrm{Al}$ とOの平衡值に関する学振推奖值 ${ }^{9}$ によると, $0.2 \%$ の $\mathrm{Al}$ と平衡する $\mathrm{O}$ 濃度は $0.000098 \%$ である.しかし 0.2\%の Al による通常の脱酸においては, Fig. 6, 8 にも示されているように, 溶鉄のO浱度は 0.004\%てい どにしか減少しないのが普通である.これは $\mathrm{Al}$ と $\mathrm{O}$ とが化学的に平衡状態に達するのに時間がかかるという よりもむしろ生成された $\mathrm{Al}_{2} \mathrm{O}_{3}$ が溶鉄から分離しにく いためと考えられる.すなわち， $\mathrm{Al}$ 添加後の溶鉄中の Oは大部分 1 次脱酸生成物として存在しており,このよ うな溶鉄に Caを添加した場合，1 次脱酸生成物の分離 性がかなり促進され， $\mathrm{Al}$ と平衡する $\mathrm{O}$ 濃度に近い值に まで急速に減少しているものと考えられる．またこの実 験結果は $\mathrm{Al}$ が存在する溶鉄中の溶解 $\mathrm{O}$ 濃度がきわめて 低いことを示しているともいえる.

このように, $\mathrm{Ca}$ の添加により $\mathrm{SiO}_{2}$ あるいは $\mathrm{Al}_{2} \mathrm{O}_{3}$ などの 1 次脱酸生成物の分離性はかなり促進されている と考えられるが，Si をたは $\mathrm{Al}$ 脱酸後の 1 次脱酸生成物 である $\mathrm{SiO}_{2}, \mathrm{Al}_{2} \mathrm{O}_{3}$ は Table 1, 2 に示してあるよう に, $\mathrm{Ca}$ の添加により $\mathrm{SiO}_{2}, \mathrm{Al}_{2} \mathrm{O}_{3}$ からそれぞれ $\mathrm{SiO}_{2}-$ $\mathrm{CaO}, \mathrm{Al}_{2} \mathrm{O}_{3}-\mathrm{CaO}$ に変化している. この組成变化が 1
次脱酸生成物の分嗺性を促進しているもの上考光られ る.

なお，本実験の場合には，Ar ガスを吹込みながら Ca を添加している. 1 次脱酸生成物の分剀性は一般的に溶 鉄を損挷することによつて促進されるが10)11) Fig. 7, 8 よりわかるように, Ar ガスの吹込みだけによつては攪 拌の効果はほ上んど認められず, $\mathrm{Ca}$ 添加後の 1 次脱酸 生成物の分雖性におよぼす Ar ガスの影響は無視してさ しつかえないこれは高周波炉を用いているため，溶鉄 はすでにかなり鄮找されているためと考えられる.

\section{5. 結論}

$\mathrm{Ca}$ を溶鉄中へ添加する方法として，いろいろ検討し た結果，耐火物ハイプを通じて添加することにより，溶 鉄中に多量の $\mathrm{Ca}$ を残留させうることを確認したので， この方法により Ca を溶鉄中に添加した場合の $\mathrm{Ca}$ 脱酸 について検討した，その結果，次の事項が明らかになつ た.

1） $1600^{\circ} \mathrm{C}, 1 \mathrm{~atm}$ 下の溶鉄中には $0.0103 \%$ 以上 の $\mathrm{Ca}$ が溶解しうる.

2) $\mathrm{Ca}$ の有している強い脱酸力を実験的に確認し, $K^{\prime}{ }_{\mathrm{Ca}}=[\% \mathrm{Ca}][\% \mathrm{O}]$ の值として $2.5 \times 10^{-5}$ を得た。

3 ) $\mathrm{Si}$ および $\mathrm{Al}$ を添加して, $\mathrm{SiO}_{2}, \mathrm{Al}_{2} \mathrm{O}_{3}$ などの 1 次脱酸生成物が残留している溶鉄中に少量の $\mathrm{Ca}$ を添 加すると, 1 次脱酸生成物の分離は急速に促進され，溶 鉄中の $\mathrm{O}$ は $\mathrm{Si}$ または $\mathrm{Al}$ と平衡する值近くまで急速に 減少する.

これは $\mathrm{Ca}$ の添加により1次脱酸生成物組成が $\mathrm{SiO}_{2}$ 一 $\mathrm{CaO}$ または $\mathrm{Al}_{2} \mathrm{O}_{3}-\mathrm{CaO}$ となり，この分蜼性がよいた めと考えられる.

\section{文 献}

1) H. Goldschmit: Iron Age, 82(1908), p. 232

2) W. S. Anderson: Raw Material, 4(1921), p. 51

3) W. Zieher: Arch. Eisenhüttenw., 5(1931), p. 299

4 ) $R . K$. Iyenger and $G . C$. Duderstadt: Trans. Met. Soc. AIME, 245(1969), p. 807

5 ) 渡辺，草川：鉄と鋼，53(1967), p. 787

6 ）小林, 大森, 三本木：鉄と鋼，56(1970), p. 998

7) D. L. Sponseller and $R$. A. Flinn: Trans. Met. Soc. AIME, 230 (1964), p. 876

8 ) 宮下: 鉄と鋼, 52(1966), p. 1049

9 ）日本学術振興会製鋼第19委員会編：製鋼反応の推 桨平衡値，(1968)，p.55[日刊工業新聞社]

10) 川和, 大久保：鉄と鋼，53(1967)，p. 1569

11) $W . A$. Fischer and $M$. Wahlster: Arch. Eisenhüttenw., 28(1957), p. 60 